\title{
Enforcement of Regulatory Bodies to Trade Indian Medicinal Plants and DNA Bar-coding In Wildlife Forensics
}

\author{
Tina Sharma ${ }^{1 *}$, Mukesh Kumar Thakar $^{2}$ and Vivek Sahajpal ${ }^{3}$ \\ 1Assistant Professor, UIAHS, Chandigarh University, Gharuan \\ 2Professor, Department of Forensic Science, Punjabi university Patiala \\ 3Assistant Director, State Forensic Science laboratory, Junga, Shimla
}

Received: 眥 February 02, 2018; Published: 酸 February 13, 2018

*Corresponding author: Tina Sharma, Assistant Professor, UIAHS, Chandigarh University, Gharuan, India

\begin{abstract}
India's diverse topology and habitat flourishes near about 45,000 species of plants. Certain species among these plants are medicinal plant species which are endemic to India. These plants are valuable for their medicinal or aromatic properties. Due to India's biodiversity abundance, plants from the wild are wildly exploited resulting in over exploitation of medicinal plants. The present review is carried out to ascertain the rules and their regulations in various states of India which are presently saving the national heritage and helping officials to apprehend herb smugglers. The review also presents the data suggesting the present scenario of advancements in the field of wild life forensic genetics to deal with such cases and technical advancements in the field of plant/part identification during the confiscations in various states.
\end{abstract}

Keywords: DNA bar-coding; Laws protecting plants; Indian Forest ACT; Wild Life Protection Act; CITES Appendix

\section{Introduction}

Wildlife forensics uses scientific tools to confiscate criminals dealing with restricted wildlife products. In recent times, very less literature could be found on crimes related to plants which are likewise smuggled for their socioeconomic importance. Many newspaper headlines mention such trade happenings around the world [1]. Various national and international regulatory bodies are also actively regulating such trade practices. But, due to lack of awareness and limited research work on these aspects of wildlife forensics, herbal medicine industry is growing. According to traffic.org India and china ranked $3^{\text {rd }}$ and $2^{\text {nd }}$ respectively to export plant material used in traditional healing systems. Plants with medicinal values are majorly collected from the wild [2]. To regulate herbal plants in trade, organizations like CITES (Convention on International Trade in Endangered Species of Wild Fauna and Flora) plays a major role by providing guidelines to the signatory bodies. CITES convention has provided three appendixes i.e. Appendix I deals with species which are threatened or near to extinction, Appendix II deals with the species which might become threatened in the coming future, Appendix III of cites deals with plant requested to be included under regulation by member signatory countries. CITES is dedicated to provide fortification to plants as well as animals worldwide [3]. CBD is a different biodiversity convention which utilizes Nagoya protocol that gives the ability to access genetic resources of the native country and also ensure fair and unbiased sharing of remuneration arising from their use of these assets between it signatory countries of the convention [4]. Laws protecting Non wood forest produce in India. According to Indian Forest Act, 1927, thirteen Chapters have been solely dedicated to the protection of wildlife flora. The law stated to facilitate the lawful and unlawful activities of forests, duties and powers to forest officers and penalties and punishments as per the state Government rules. The act defines itself by stating the following definition.

"Consolidate the law related to forest, the transit of forest produce and the duty livable on timber and other forest produce". The word "forest produce" include timber, charcoal, caoutchouc, 
catechu, wood-oil, resin, natural varnish, barck, ac, mahua flower, mahua seeds and myrabolams. The chapter 1 clause $2(4 \mathrm{~b})$ in the Indian forest act also gives the liberty to add the trees, leaves, flowers, fruits, grass, creepers reeds, moss and all parts of such plant produce and other parts or produce that are not directly mentioned in the act to be protected and preserved by same regulations prescribed by the act [5]. By describing the forest produce broadly, the Indian forest act take the responsibility to even protect the non-economical plants which are mentioned or not mentioned in the act [6]. Basically the non-wood forest produce is economically important produce of the forest other than wood, which is being exploited by the law breakers to earn the instant money [7]. NTFPs are the active ingredient of budding small scale and fully developed large scale industries to commercialize the products to earn profit [8]. The produce (medicinal herbs) is profitable forest produce which is often used by pharmaceutical industries to launch health related products in the market [9]. These companies or organizations have permits and licenses to collect the permitted plant varieties from the locals [10]. The local herb dwellers have certain powers given by state and center governments through Indian biodiversity act etc. to earn their living by using their traditional knowledge of gathering wild flora [11]. This lawful business turns illegal when these dwellers and industrial set up without prior permissions gather and motivate forest dweller to supply the produce in bulk [12]. With limited knowledge of endangered and threatened species restricted from wild collection or deliberate collection to earn instant money is the main reason of utilization of forest produces [13].

According to the chapter 2 of INDIAN FOREST ACT which defines the reserve forest area under section 28 clause (f) which states "Any person who fells, girdles, lops, taps or burns any tree or strip off the bark leaves from, or otherwise damages the same and clause (g) removes any forest produce shall be punishable with imprisonment for a term which may extend to six months or with fine or both in comparison to the damage [14]. Similar State Provision according to section 26. In this Bihar Sec. (26) the Forest range Offence is said to be cognizable and punishable with sentence for a maximum term of 6 months which may extend up to 24 years or with fine up to 5000/- or both + compensation[15]. In Gujarat Sec (26) of Indian Forest Act, punishment up to 1 year or with fine up to 1000/. In Himachal Pradesh according to Sec (26) punishment for forest offence is two years along with the fine of 5000. In Madhya Pradesh \& West Bengal I year punishment is decided for the offender and fine of 2000 is imposed on such illegal activities. In Uttar Pradesh the maximum imprisonment for violating the rules of Indian forest act maximum punishment of 2 years or a fine of Rs. 5000/- or both is imposed on the offender when proved guilty for violation of sect. (26) (b), (h) (i) (j) but if the equivalent crime is committed second time and subsequently, sentence up to 2years or fine up to Rs. 20,000 but not less than Rs. $5000 /$ - or both are imposed [16]. For the abuse other clauses of Sec. (26) imprisonment up to six month or a fine up to Rs. 1000/- or both is provided and for second and subsequent violation of these subsections is punishable by imprisonment up to six month or a fine up to Rs. 2000/- or both. Similarly, in chapter 3 which defines the protected forest areas under section 33 clauses is punishable with same penalty as is defined for the activities in reserve forest declared by the officials [17].

\section{State Provisions According to Section 33}

In Bihar state according to the section (33) imprisonment minimum of six months, maximum 2 of years fine minimum Rs. 1000/- maximum Rs. 5000/- imprisonment + fine both is availed to punish the convicted criminal but in case of Haryana:-15Sec (33) Imprisonment up to 1 year or with fine up to Rs. 1000 is imposed for the conviction in similar crime [18]. In Madhya Pradesh punishment lesser than Bihar Punishment is decided upto1 year or with fine up to Rs. 1000/ [19]. In Maharashtra punishment for violating Indian forest act rules is only up to 1 year or with fine up to Rs. 2000. Similarly in West Bengal Sec. (33) up to 1 year or with fine up to Rs. 1000 only. Uttar Pradesh is strict in terms of punishment for forest offences as their Maximum imprisonment of two years or fine up to Rs. 5000/- or both and for second and subsequent violation maximum term of 2 years or fine up to Rs. 10,000/-[20]. Wildlife protection Act. 1972 and the listed species Wildlife protection Act. 1972, SCHEDULE VI six plants are protected strictly by this Act which offers severe penalties to the offenders [20].The penalty is minimum 3 years which may extend depending upon the severity of the illegal activity and with fine of rupees 25000. If the convict is license holder the license will be cancelled and upon repetitive offence the penalty may increase up to 7 years [21]. Chapter ii of WPA outlines the protection of definite plants by declaring two clauses which are as follows:

a) Willfully pick, uproot, damage, destroy, acquire or collect any specified plant from any forest land and any area specified, by notification, by the Central Government.

b) Posses, sell, offer for sale, or transfer by way of gift or otherwise, or transport any specified.

Plant, whether alive or dead, or part or derivative thereof: Provided that nothing in this section shall prevent a member of a scheduled tribe, subject to the Provisions of Chapter IV, from picking, collecting or possessing in the district he resides any Specified plant or part or derivative thereof for his bona fide personal use." Further in section 17B of chapter 2 the law provides relaxation to educational institutions, researchers, scientific institutions to collect plant samples by acquiring the permission from chief wildlife warden [22]. The plants mentioned in this section are also prohibited to be cultivated without the prior permission from chief wildlife warden. The license is necessary to commercially cultivate the plants and sell them to the wholesalers. These rules are followed more strictly in protected and preserved forest areas or any such areas which are being declared protected by the government officials [23]. 
First species listed is Beddomescycad (Cycas beddomei) is native to trimulla hills of Andhra Pradesh. The male cones incorporate bioflavonoid which is used in the management of rheumatoid arthritis and muscle pains. It is listed in cites Appendix1 and Wild Life Protection Act 1972 Schedule 6 and CITES appendixes [24]. Blue Vanda (Vanda soerulec) is another endangered native plant of India which is found at $2000 \mathrm{~m}-3000 \mathrm{~m}$ altitude. The plant is traded for its ornamental properties [25]. Kuth (Saussurea lappa) is list in WPA is also listed in CITES appendix 1. It is found at 2500 to $3000 \mathrm{~m}$ Himalayas, Jammu Kashmir forest areas, Western Ghats, and kishenganga valley. It is traded by the name kuth kauri, kuth mithi. Basically the root of the plant contains Sesquiterpene lactones which are used to treat serious ailments like asthma, inflammatory diseases, and ulcer and stomach problems [26]. In India, only two genera namely Cypripedium and Paphiopedilum listed in Cites 1 and WPA schedule 6 can be found in Himalayan and NorthEast Indian region except one species of Paphiopedilum which is endemic to Western Ghats. This orchid specie is specifically traded for its ornamental and aromatic properties [27]. Pitcher plant's natural habitat is India and mostly originates in Jarain area of the Jaintia Hills, the Baghmara area of the Garo Hills of Meghalaya or in Assam.

The plant is exploited from the wild for its ornamental and medicinal use. It is enumerated in cites Appendix1 and Wild Life Protection Act 1972 Schedule 6 [28]. Red Vanda is listed CITES appendix 1 and schedule 6 of WPA is found in Meghalaya. It is being traded internationally for its ornamental properties [29]. Customs Act. 1962, regulates the import and export of India. Under this act, section 112 defines the penalties for improper import and export of any good which is restricted by any law in action at that present time will be confiscated and fine of rupees 5000 or value of goods whichever is higher will be imposed. According to the section 118 and 119 deals with smuggling goods and goods used to conceal the smuggling goods. The section give the power to custom officers to seal any import and export goods and goods which are used to conceal the smuggled goods which are brought out of the limits of custom area and custom ports[30,31].

International treaties to protect plants

a) International Treaty on Plant Genetic Resources for Food and Agriculture (IT PGRFA)

Secretary-General of the United Nations [32]. b) The International Tropical Timber Agreement (ITTA, 1983), International Tropical Timber Agreement, 1994 (ITTA, 1994 or ITTA2) [33].

c) Convention on International Trade in Endangered Species of Wild Fauna and Flora, also known as the Washington Convention) [34].

d) Convention on the Conservation of European Wildlife and Natural Habitats, also known as the Bern Convention (or Berne Convention), council of Europe [35].

e) Convention on Biological Diversity (CBD) SecretaryGeneral of the United Nations [36].

f) Conservation of Antarctic Fauna and Flora SecretaryGeneral of the United Nations [37].

\section{Trade of restricted medicinal herbs}

Wildlife trafficking have emerged with its medium from physical markets to online e commerce sites. Numbers of species are being sold on the web portals with dedicated websites, WebPages through face book, Instagram YouTube and many more social networking sites illegally just because these platforms provide greater anonymity to the seller. The plants which are being sold on these platforms are basically threatened rare or endangered [38]. EVAN MATI 307 medicinal products corresponding to ca. 283 species. Ten species out of 35 were found to be locally endangered and listed in IUCN [39]. The plants are also advertised online on daily bases and delivered without being securitized by the authorities. This may be due to lack of awareness on this issue specifically in India. Figure number 1-4 clearly shows such online business [40].

\section{DNA Bar-Coding to Identify Plants in Trade}

DNA bar-coding is presently quick and precise tool to identify plant species. Chloroplast genome off plant sequencing can convey a consistent barcode to accurately identify plants. The development of specific barcodes provides a new approach to distinguish closely related Species to tackle illegal trade of medicinal plants in trade [41]. Table 1 shows the ingenuities of Investigation work in wildlife forensics with respect to flora. The scanty research work in this area provide ample scope to scientist and researcher to explore this budding field of wild life forensics and establish barcode libraries specific to plant families or location specific libraries showing mutations if any [42-46].

Table 1: Shows the research work in the field of wildlife forensic.

\begin{tabular}{|c|c|c|c|c|}
\hline & Part used & Medicinal properties & Title of the Study \\
\hline Rauvolfia serpentine & Root Extracts & Antihypertensive drug & $\begin{array}{c}\text { Forensic identification of Indian snakeroot } \\
\text { (Rauvolfia serpentina Benth. ex Kurz) using } \\
\text { DNA bar-coding }\end{array}$ & Eurlings et al. [43] \\
\hline $\begin{array}{c}\text { Hoodia (Ceropegieae: } \\
\text { Apocynaceae) }\end{array}$ & Stems & $\begin{array}{c}\text { Compound activates the human bitter } \\
\text { receptor TAS2R14 by inducing the } \\
\text { release of cholecystokinin, which is } \\
\text { known to suppress appetite and thirst }\end{array}$ & $\begin{array}{c}\text { Forensic Identification of CITES Protected } \\
\text { Slimming Cactus (Hoodia) Using DNA Bar- } \\
\text { coding }\end{array}$ & Gathier [44] \\
\hline
\end{tabular}




\begin{tabular}{|c|c|c|c|c|}
\hline Cannabis Sativa & $\begin{array}{c}\text { Leaves, Stems, } \\
\text { Flowers }\end{array}$ & Euphoric Fealing & $\begin{array}{c}\text { Species Identification of Cannabis sativa Using } \\
\text { Real-Time Quantitative PCR (qPCR) }\end{array}$ & Johnson [45] \\
\hline $\begin{array}{c}\text { Salvia divinorum } \\
\text { (diviner's sage) }\end{array}$ & Leaves, Stem & $\begin{array}{c}\text { Hallucinogenic compound to induce } \\
\text { induce hallucinatory visions }\end{array}$ & $\begin{array}{c}\text { DNA identification of Salvia divinorum } \\
\text { samples. }\end{array}$ & Murphy [46] \\
\hline
\end{tabular}

\section{Conclusion}

Due to India's biodiversity abundance, plants from the wild are wildly exploited resulting in depletion of important medicinal herbs. The illegal trade practices often go unnoticed because lack of awareness and lesser punishments as compared to the reimbursements involved to such trades practices. The punishments mentioned as such in the paper are demonstrating the lack of momentousness of law enforcement toward this serious issue. The Scanty literature on DNA Bar-coding provide ample opportunities of research in this untouched area of wildlife genetics which will directly benefit the law enforcement agencies to convict forest offenders.

\section{References}

1. Thakar MK, Sharma T, Sahajpal V (2017) Illegal trade of Medicinal Plants approaching wildlife forensics: Indian Scenario. Editorial Board pp. 130.

2. Prabhu S, Vijayakumar S, Yabesh JM, Ravichandran K, Sakthivel B (2014) Documentation and quantitative analysis of the local knowledge on medicinal plants in Kalrayan hills of Villupuram district, Tamil Nadu, India. Journal of ethno pharmacology 157: 7-20.

3. Rosen GE, Smith KF (2010) Summarizing the evidence on the international trade in illegal wildlife. EcoHealth 7(1): 24-32.

4. Buck M, Hamilton C (2011) The Nagoya Protocol on access to genetic resources and the fair and equitable sharing of benefits arising from their utilization to the Convention on Biological Diversity. Review of European, Comparative \& International Environmental Law 20(1): 4761.

5. Bhullar L (2008) The Indian forest rights act 2006: a critical appraisal. Law Env't \& Dev. J 4:20.

6. Roth HH, Merz Gunter (1997) Wildlife resources: a global account of economic use. Springer Science \& Business Media.

7. Elmahi AG, Magid TD (2002) The role of the private sector, civil society and NGOs in the formulation and implementation of National Forest Policies and National Forest Programmes in Sudan. In Prepared as a contribution of the Sudan Forests National Corporation to the Regional Workshop held by FAO/RNE in Khartoum pp. 26-27.

8. Shiva MP (1998) Inventory of Forest Resources for Sustainable Management \& Biodiversity Conservation with Lists of Multipurpose Tree Species Yielding Both Timber \& Non-timber Forest Products (NTFPs), and Shrub \& Herb Species of NTFP Importance. Indus Publishing.

9. Balick MJ, Cox PA (1997) Ethno botanical research and traditional health care in developing countries. Medicinal plants for forest conservation and health care 92: 12-23.

10. Gazzaneo LR, De Lucena RF, de Albuquerque UP (2005) Knowledge and use of medicinal plants by local specialists in a region of Atlantic Forest in the state of Pernambuco. Journal of Ethno biology and Ethno medicine, Northeastern Brazil 1(1): 9.

11. Sher H, Hussain F (2009) Ethno botanical evaluation of some plant resources in Northern part of Pakistan. African journal of Biotechnology $8(17)$.
12. Saxena NC (1997) The saga of participatory forest management in India. CIFOR, Indonesia pp. 214.

13. Schippmann U, Leaman DJ, Cunningham AB (2002) Impact of cultivation and gathering of medicinal plants on biodiversity: global trends and issues. Biodiversity and the ecosystem approach in agriculture, forestry and fisheries.

14. Rahman LM (1927) The Forest Act.

15. Chandrasekharan NS (1988) Environmental Protection: Two Steps forward, One Step Back. Journal of the Indian Law Institute 30(2): 184195.

16. Saberwal VK (1996) Pastoral politics: Gaddi grazing, degradation, and biodiversity conservation in Himachal Pradesh, India. Conservation Biology 10(3): 741-749.

17. Sundar N (2000) Unpacking the 'joint 'in joint forest management. Development and change. 31(1): 255-279.

18. Sarin M (2005) Laws, lore and logjams: critical issues in Indian forest conservation. London: International Institute for Environment and Development.

19. Saxena NC (1997) The saga of participatory forest management in India. CIFOR, Indonesia.

20. Bose I (2010) How did the Indian forest rights Act, 2006, emerge? Institutions for Pro-Poor Growth.

21. Kunte K (2008) The Wildlife (Protection) Act and conservation prioritization of butterflies of the Western Ghats, southwestern India. Current Science 25: 729-35.

22. Arora K (2002) Forest Laws the Wildlife Protection Act, 1972 as amended by the Wild (Protection). Amendment Act.

23. Ninan KN, Sathyapalan J (2005) The economics of biodiversity conservation: a study of a coffee growing region in the Western Ghats of India. Ecological Economics 55(1): 61-72.

24. Raju AS, Jonathan KH (2010) Reproductive ecology of Cycas beddomei Dyer (Cycadaceae), an endemic and critically endangered species of southern Eastern Ghats. Current Science 99(12): 1833-1840.

25. Roy AR, Patel RS, Patel VV, Sajeev S, Deka BC (2011) A symbiotic seed germination, mass propagation and seedling development of Vanda coerulea Griff ex. Lindl.(Blue Vanda): An in vitro protocol for an endangered orchid. Scientia Horticulture 128(3): 325-331.

26. Madhuri K, Elango K, Ponnusankar S (2012) Saussurea lappa (Kuth root): review of its traditional uses, photochemistry and pharmacology. Oriental Pharmacy and Experimental Medicine 12(1): 1-9.

27. Misra S, Misra S (2007) Orchids of India. Bishen Singh Mahendra Pal Singh.

28. Godt M, Hamrick J (1998) Allozyme diversity in the endangered pitcher plant Sarracenia rubra ssp. Alabamensis (Sarraceniaceae) and its close relative S. rubra ssp. rubra. American Journal of Botany 85(6): 802.

29. Seeni S, Latha PG (1992) Foliar regeneration of the endangered red Vanda, Renanthera imschootiana Rolfe (Orchidaceae). Plant cell, Tissue and organ Culture 29(3): 167-172.

30. Mishra P, Subramanian A, Topalova P (2008) Tariffs, enforcement, and customs evasion: Evidence from India. Journal of public Economics 92(10-11): 1907-1925. 
31. Das P (2012) Drug trafficking in India: A case for border security. New Delhi: Institute for Defense Studies and Analyses.

32. Upadhyay SK (2001) Crime in India. Work product of the $116^{\text {th }}$ International Training Course. Resource Material Series 58.

33. Siang LE International treaty on plant genetic resources for food and agriculture (ITPGRFA). University Putra Malaysia.

34. Garrison JL (1994) Convention on International Trade in Endangered Species of Wild Fauna and Flora (CITES) and the Debate Over Sustainable Use. Pace Environmental Law Review 12(1): 301.

35. Jen S (1999) The Convention on the conservation of European wildlife and natural habitats (Bern, 1979): procedures of application in practice.

36. Laikre L (2010) Genetic diversity is overlooked in international conservation policy implementation. Conservation Genetics 11(2): 34954 .

37. Dubner BH (2005) On the basis for creation of a new method of defining international jurisdiction in the Arctic Ocean. Missouri Environment Law \& Policy Review 13(1): p.23.

38. Yongqi Z Current Status of Forest Genetic Resources in China and National Strategies and Policies. In Extended abstracts p.13.

39. Mati E, de Boer H (2011) Ethno botany and trade of medicinal plants in the Qaysari Market, Kurdish Autonomous Region, Iraq. Journal of Ethno pharmacology 133(2): 490-510.
40. Martin R (2002) Financialization of daily life. Temple University Press, USA.

41. Group CP, Hollingsworth PM, Forrest LL, Spouge JL, Hajibabaei M, et al. (2009) A DNA barcode for land plants. Proceedings of the National Academy of Sciences 106(31): 12794-12797.

42. New master SG, Fazekas AJ, Ragupathy S (2006) DNA bar-coding in land plants: evaluation of rbcL in a multigame tiered approach. Botany 84(3): 335-341.

43. Eurlings M, Lens F, Pakusza C, Peelen T, Wieringa JJ, et al. (2013) Forensic identification of Indian snakeroot (Rauvolfia serpentina Benth. ex Kurz) using DNA bar-coding. Journal of forensic sciences 58(3): 822-830.

44. Gathier G, Niet T, Peelen T, Vugt RR, Eurlings M, et al. (2013) Forensic identification of CITES protected slimming cactus (Hoodia) using DNA bar-coding. Journal of forensic sciences 58(6): 1467-1471.

45. Johnson CE, Premasuthan A, Satkoski Trask J, Kanthaswamy S (2013) Species Identification of Cannabis sativa Using Real-Time Quantitative PCR (qPCR). Journal of forensic sciences 58(2): 486-490.

46. Murphy TM, Bola G (2013) DNA identification of Salvia divinorum samples. Forensic Science International: Genetics 7(1): 189-193.
(C) This work is licensed under Creative

To Submit Your Article Click Here:

Submit Article

DOI: $10.32474 /$ PRJFGS.2018.01.000105

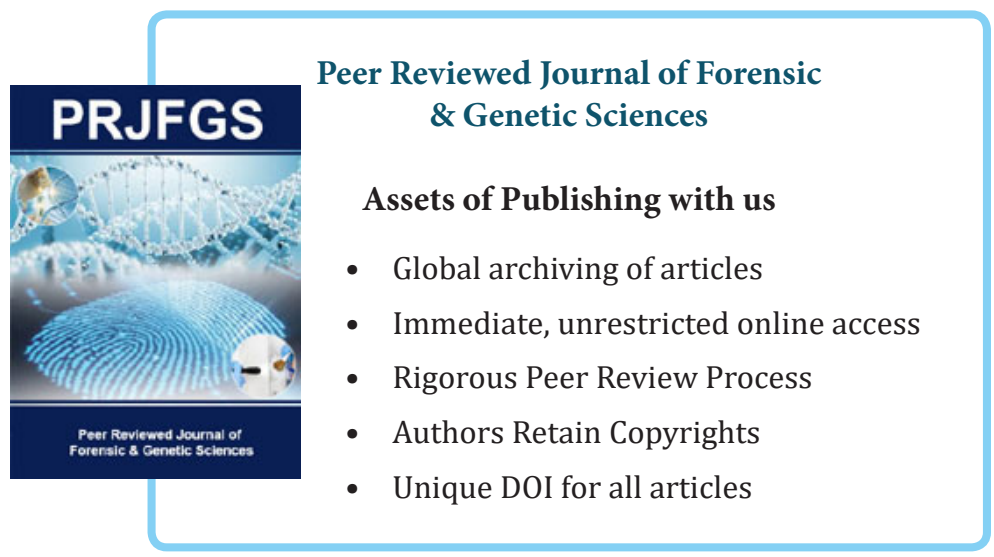

